\title{
PERBANDINGAN PROJECT BASED LEARNING DAN GUIDED INQUIRY PADA PENGEMBANGAN PEMAHAMAN KONSEP PESERTA DIDIK SMA
}

\author{
La Ode Kaharudin ${ }^{1}$ dan Veni Rosnawati ${ }^{2}$ \\ 1, 2 Pendidikan Biologi, Universitas Muslim Buton \\ J1. Betoambari No. 150, Kota Baubau 93721 \\ ${ }^{1}$ Email: kaharudinkendari@gmail.com \\ ${ }^{2}$ Email: venirosnawati27@gmail.com
}

\begin{abstract}
ABSTRAK
Perbandingan Project Based Learning dan Guided Inquiry pada Pengembangan Pemahaman Konsep Peserta Didik SMA. Penelitian ini bertujuan untuk mengetahui perbandingan pemahaman konsep pada materi Sistem Ekskresi antara peserta didik yang diajar menggunakan Project Based Learning (PjBL) dan Guided Inquiry (GI). Penelitian ini berupa quasi experiment dengan rancangan pretest-posttest non-equivalent control group design. Populasi penelitian ini adalah peserta didik kelas XI SMA Negeri 1 Kendari, Tahun Ajaran 2018/2019. Sampel penelitian ini adalah peserta didik kelas XI MIPA 1 sebagai kelompok eksperimen yang diajarkan dengan model PjBL dan peserta didik kelas XI MIPA 2, diajar dengan model GI. Data dianalisis secara deskriptif dan inferensial menggunakan program SPSS. Kesimpulan dari penelitian ini adalah (1) Terdapat perbedaan yang signifikan pemahaman konsep pada materi sistem ekskresi antara peserta didik yang diajar dengan model pembelajaran project based learning dengan peserta didik yang diajar dengan model guided inquiry dibuktikan dengan adanya perbedaan nilai ratarata posttest peserta didik dan nilai G-gain pada masing-masing indikator pemahaman konsep, (2) Peserta didik kelas model project based learning memperoleh peningkatan pemahaman konsep yang lebih tinggi secara signifikan dari kelompok peserta didik pada kelas model guided inquiry.
\end{abstract}

Kata Kunci: Project based learning, guided inquiry, pemahaman konsep.

\begin{abstract}
Comparison of Project Based Learning and Guided Inquiry in the Development of Understanding of High School Student Concepts. This study aims to compare the understanding of concepts in the Excretion System material between students taught using Project Based Learning (PjBL) and Guided Inquiry (GI). This research is in the form of a quasi experiment with a pretest-posttest non-equivalent control group design. The population of this research is the XI grade students of SMA Negeri 1 Kendari, 2018/2019 Academic Year. The sample of this study was students of Class XI MIPA 1 as an experimental group taught by the PjBL model and students of Class XI MIPA 2, taught by the GI model. Data were analyzed descriptively and inferentially using the SPSS program. The conclusions of this study are (1) There is a significant difference in the understanding
\end{abstract}


of concepts in the excretion system material between students taught with project based learning models and students taught with guided inquiry models as evidenced by differences in the average value of students' posttest and G-gain value in each indicator of concept understanding, (2) Students of the project based learning model class gain significantly higher concept understanding than the group of students in the guided inquiry model class.

Keywords: Project based learning, guided inquiry, concept understanding.

\section{PENDAHULUAN}

Pembelajaran biologi bertujuan mendorong peserta didik secara aktif memahami materi Biologi melalui: penaralan, berpikir kritis dan kreatif, penyelidikan ilmiah serta penerapannya pada kehidupan nyata. Permasalahan yang sering dihadapi oleh guru adalah bagaimana memahamkan konsep biologi dengan tepat kepada peserta didik (Hakim, 2018). Diki (2013) melaporkan bahwa kesulitan dalam pembelajaran biologi disebabkan oleh kesulitan memahami, kesulitan menghubungkan materi biologi, dan sifat dari materi pada umumnya.

Pemahaman konsep peserta didik di SMAN 1 Kendari mengenai penguasaan materi ujian nasional dengan materi yang diuji struktur dan fungsi makhluk hidup termasuk materi sistem ekskresi mengalami penurunan pada tiga Tahun terakhir, yakni mulai Tahun 2016, 2017 dan 2018. Persentase peserta didik yang menjawab benar Tahun 2016 adalah 74,74\%, Tahun 2017 adalah 59,53\%, dan Tahun 2018 adalah 63,10\% (Kementerian Pendidikan dan Kebudayaan, 2016, 2017, 2018).

Project based learning merupakan model pembelajaran yang melibatkan suatu proyek dalam proses pembelajaran. Proyek yang dikerjakan oleh peserta didik dapat berupa proyek perseorangan atau kelompok dan dilaksanakan dalam jangka waktu tertentu secara kolaboratif, menghasilkan sebuah produk, yang hasilnya kemudian akan ditampilkan dan dipresentasikan. Pelaksanaan proyek dilakukan secara kolaboratif dan berfokus pada pemecahan masalah yang berhubungan dengan kehidupan peserta didik.

Project based learning merupakan model pembelajaran yang menekankan pelaksanaan proyek dalam setiap pembelajaran. Ong dan Borich (2006) menjelaskan langkah-langka project based learning, yaitu conceive (memahami), design (merancang), 
implement (pelaksanaan), dan operate (mengoperasikan). Salah satu model pembelajaran yang peserta didik terlibat aktif menggunakan proses fisik untuk menemukan beberapa konsep dan prinsip materi yang sedang dipelajari adalah inquiry.

Model inquiry merupakan model yang melibatkan peserta didik secara langsung dalam proses pembelajaran, seperti merumuskan masalah atau menyelidiki masalah secara luas untuk kemudian membangun pemahaman dan pengetahuan baru. Proses-proses sains dalam sintaks inquiry antara lain: (1) orientasi (pengenalan), (2) menyajikan pertanyaan atau masalah, (3) merumuskan hipotesis, (4) merancang percobaan, (5) melakukan percobaan, (6) mengumpulkan dan menganalisis data, dan (7) membuat kesimpulan, (Sanjaya 2006).

Model inquiry bila dilihat besar kecilnya informasi dari guru kepada peserta didik dalam proses pembelajaran, dibedakan tiga kelompok, yaitu: 1) Inquiry terbimbing, 2) Inquiry bebas, dan 3) Inquiry yang dimodifikasi (Margono, 1995). Lebih lanjut Kurniawan, (2012) melaporkan penerapan guided inquiry memberikan pengaruh terhadap prestasi.

Upaya yang dapat dilakukan untuk menyelesaikan masalah tersebut adalah dengan memilih model pembelajaran yang tepat. Model yang tepat adalah yang berpusat pada peserta didik SMA sehingga mampu mengaplikasikan life skill dalam kehidupan seharihari. Berdasarkan hal tersebut maka penting dilakukan penelitian tentang "perbandingan model project based learning dan guided inquiry pada pengembangan pemahaman konsep peserta didik SMA".

\section{METODE PENELITIAN}

Jenis penelitian ini adalah quasi experimental (eksperimen semu). Teknik pengumpulan data dilakukan dengan tes, untuk mengukur pemahamana konsep. Teknik analisa data menggunakan analisa deskriptif untuk mendeskripsikan nilai yang diperoleh masing-masing kelas dalam bentuk rata-rata, nilai maksimum, nilai minimum, standar deviasi dan analisa inferensial digunakan untuk menguji hipotesis penelitian. Penelitian ini menggunakan desain pretest-posttest group design (Cohen, et al., 2007), dengan pengolahan data menggunakan SPSS 21. Seperti yang ditunjukkan pada tabel 1 berikut ini: 
Tabel 1 Desain Penelitian Pretest-Posttes Group Design

\begin{tabular}{cccc}
\hline Kelompok & Awal & Perlakuan & Akhir \\
\hline Eksperimen 1 & Y1 & P1 & Y2 \\
Eksperimen 2 & Y1 & P2 & Y2 \\
\hline
\end{tabular}

Keterangan:

$\mathrm{Y} 1=$ pretest $\mathrm{P} 1=$ pembelajaran project based learning

$\mathrm{Y} 2=$ posttes $\mathrm{P} 2$ = pembelajaran guided inquiry

Eksperimen 1 = XI MIPA 1

Eksperimen $2=$ XI MIPA 2

Penelitian dilaksanakan salah satu SMAN di Sulawesi Tenggara pada semester genap Tahun Pelajaran 2018/2019 yaitu pada bulan Februari-Maret 2019. Sampel penelitian ini adalah peserta didik kelas XI berjumlah 72 orang. Penelitian melibatkan dua variabel, yaitu variabel independen (bebas) dan variabel dependent (terikat). Variabel bebas terdiri atas penerapan model project based learning dan model guided inquiry, sedangkan variabel terikat adalah pemahaman konsep. Instrument yang digunakan pada penelitian ini adalah instrument tes yaitu tes uraian untuk mengukur pemahaman konsep biologi peserta didik.

\section{HASIL DAN PEMBAHASAN}

Perbandingan data pemahaman konsep biologi berupa nilai pretest, posttest dan Ngain materi sistem ekskresi yang dilakukan kelas project based learning dan guided inquiry dirangkum pada Tabel 2, berikut ini:

Tabel 2. Rangkuman Hasil Analisis Deskripsi Pemahaman Konsep

\begin{tabular}{cccccccc}
\hline \multirow{2}{*}{$\begin{array}{c}\text { Parameter } \\
\text { Deskriptif }\end{array}$} & \multicolumn{5}{c}{ Model Pembelajaran dan Jenis Data } \\
\cline { 2 - 4 } \cline { 7 - 8 } & Pretest & Posttest & N-gain & & Pretest & Posttest & N-gain \\
\cline { 2 - 4 } & 53,53 & 93,91 & 0,87 & & 50,85 & 88,78 & 0,77 \\
Rata-rata & 3,49 & 5,70 & 0,07 & & 7,13 & 8,45 & 0,14 \\
SD & 46,15 & 84,62 & 0,71 & & 30,77 & 53,85 & 0,33 \\
Min & 65,38 & 96.15 & 0,93 & & 61,54 & 96,15 & 0,92 \\
Maks & &
\end{tabular}

Keterangan: $\quad \mathrm{PjBL}=$ project based learning $(\mathrm{N}=36)$, kelas XI MIPA 1

GI = guided inquiry $(\mathrm{N}=36)$, kelas XI MIPA 1 
Tabel 2 menunjukkan bahwa peserta didik memperoleh peningkatan pemahaman konsep cukup tinggi secara kuantitatif setelah proses belajar menggunakan model project based learning dan guided inquiry. Hal ini mengindikasikan bahwa peserta didik dengan kemampuan rendah sebagian mengalami kesulitan memahami materi sistem ekskresi melalui guided inquiry dibandingkan dengan model project based learning. Peningkatan pemahaman konsep yang dinormalisasi ( $N$-gain) termasuk kategori tinggi secara rata-rata pada hasil pembelajaran project based learning dan guided inquiry.

Deskripsi data $\mathrm{N}$-gain menunjukkan sebagian peserta didik yang memperoleh peningkatan (N-gain) pemahaman konsep di atas nilai 0,3 (kategori sedang), tetapi sebagian juga juga memperoleh $\mathrm{N}$-gain pemahaman konsep di atas 0,7 (kategori tinggi). Pada kelas project based learning memperoleh peningkatan pemahaman konsep yang dinormalisasi (N-gain) pada kategori tinggi secara total, sedangkan pada kelas guided inquiry sebagian yang memperoleh $\mathrm{N}$-gain pemahaman konsep kategori tinggi dan sedang. Jumlah peserta didik yang memperoleh N-gain pemahaman konsep kategori tinggi lebih banyak pada kelas project based learning.

Indikator pemahaman konsep pada penelitian ini meliputi: menafsirkan, mencontohkan, mengelompokkan, merangkum, menyimpulkan, menjelaskan dan membandingkan. Deskripsi nilai rata-rata peningkatan pemahaman konsep pada setiap indikator disajikan pada Gambar 1.

Gambar 1. Deskripsi nilai rata-rata peningkatan (N-gain) pada setiap indikator pemahaman konsep pembelajaran menggunakan model project based learning dan guided inquiry dengan pengolahan data SPSS 21.

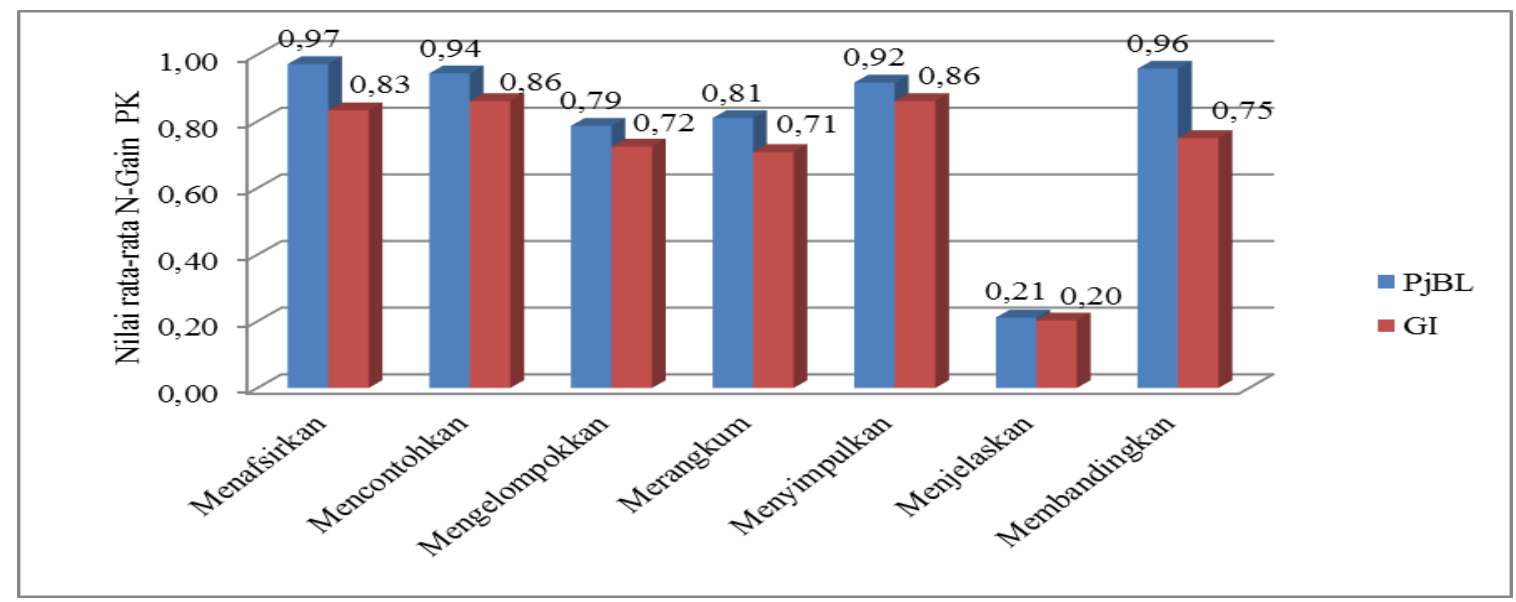


Nilai rata-rata peningkatan (N-gain) pada indikator menafsirkan, mencontohkan, mengelompokkan, merangkum, menyimpulkan dan membandingkan termasuk kategori tinggi baik pada hasil pembelajaran project based learning dan guided inquiry. Pada indikator menjelaskan yaitu sebesar 0,21 (kategori rendah) pada hasil pembelajaran project based learning dan kelas model guided inquiry sebesar 0,20 (kategori rendah).

Berdasarkan hasil uji perbandingan nilai rata-rata $\mathrm{N}$-gain pemahaman konsep antara kedua kelas menggunakan uji-t diperoleh thit $=3,560>$ ttabel $=0,001$. Hal ini menunjukkan ada perbedaan yang signifikan. Peserta didik pada kelas project based learning memperoleh peningkatan pemahaman konsep yang lebih baik dari kelas pembelajaran guided inquiry.

\section{PEMBAHASAN}

Perbandingan Project Based Learning dan Guided Inquiry pada Pengembangan Pemahaman Konsep Peserta Didik SMA. Berdasarkan hasil analisis deskriptif yang digambarkan dengan nilai rata-rata pretest, posttest dan $\mathrm{N}$-gain menunjukkan bahwa model project based learning lebih efektif dibanding dengan model guided inquiry. Dimana proses tahapan pembelajaran project based learning, peserta didik dilatih memahami pertanyaan-pertanyaan yang terkait dengan topik proyek yang diberikan guru diawal pembelajaran dan kemudian melatih bagaimana siswa mampu menjawab pertanyaanpertanyaan yang dimaksud dari pertanyaan yang diajukan. Model project based learning membantu siswa dalam proses penyelidikan dan mendorong siswa untuk menemukan jawaban atas pertanyaan investigasi yang rumit.

Dalam proses pembelajaran project based learning peserta didik dituntut merancang proyek dengan berbagai jenis permasalahan dan bekerja sama dalam hasil-hasil penyelidikan. Sejalan dengan pendapat Bell (2010), melaporkan melalui model project based learning peserta didik dapat menyelesaikan masalah dunia nyata dengan merancang keingintahuan yang dimiliki tiap peserta didik, merencanakan pembelajaran, mengorganisir proyek. Sedangkan pada guided inquiry, tahapan pembelajaran banyak dicampuri guru. Guru banyak mengarahkan dan memberikan petunjuk seperti pertanyaan pengarahan selama proses inquiry: penyelidikan, berhipotesis, pengumpulan data dan penarikan 
kesimpulan. Sehingga dari perbedaan itu,tergambar perbedaan peserta didik dalam mengembangkan pengetahuan yang dimiliki dalam menghadapi menyelesaikan suatu masalah.

Model project based learning dan guided inquiry merupakan model pembelajaran inovatif yang berlandaskan paham konstruktivistik. Paham konstruktivistik ini membiasakan peserta didik untuk menemukan sesuatunya dengan sendiri dan bergelut dengan ide-ide. Esensi dari teori konstruktivisme adalah siswa harus menemukan dan mentransformasikan suatu informasi kompleks ke situasi lain, sehingga membutuhkan proses berpikir agar siswa dapat menemukan ide-ide tersebut (Kunandar, 2007). Kedua model pembelajaran tersebut menekankan proses sains dalam pelaksanaannya. Model project based learning memiliki nilai lebih dalam pelaksanaannya yaitu memuat masalah dunia maya (real world problem), memberi apresiasi terhadap hasil karya siswa, otonomi siswa di dalam proses pembelajaran, mendukung proses pembelajaran yang berlandaskan learning by doing sehingga model project based learning akan lebih baik di dalam meningkatkan pemahaman konsep (Thomas, 2000).

Karakteristik model project based learning yang bersifat terprogram menyebabkan intensivitas kolaborasi diantara masing-masing anggota kelompok baik secara formal maupun informal semakin tinggi. Lebih lanjut, hal tersebut akan mendukung proses pembelajaran sehingga proses asimilasi dan akomodasi pengetahuan peserta didik akan terfasilitasi dengan baik. Di dalam tahapan menentukan tema proyek, guru bersama-sama peserta didik menentukan tema proyek yang terkait dengan kehidupan sehari-hari. Partisipasi peserta didik di dalam penentuan tema proyek akan memberikan dampak yang signifikan bagi keberlangsungan proses belajar mengajar. Di samping itu, dalam penentuan tema proyek, peserta didik juga diminta untuk merumuskan pertanyaan penuntun (driving question) yang akan menentukan bagaimana rancangan, proses, dan produk proyek ke depannya. Penentuan driving question ini akan mengembangkan salah satu aspek dari pemahaman konsep yaitu merumuskan masalah (Panasan and Nuangchalerm, 2010). Model project based learning tidak hanya sebatas merumuskan driving question, akan tetapi juga melibatkan peserta didik di dalam rumusan masalah alternatif yang kelak dapat membantu proses pengerjaan proyek. Pertanyaan yang diharapkan adalah pertanyaan yang 
mengundang peserta didik untuk berpartisipasi dalam proses berpikir. Tahap ini memberikan peserta didik kesempatan dalam berpikir secara abstrak, dimana juga untuk menumbuhkan pemahaman konsep peserta didik. Hal ini dapat dicermati dari cara pandang dan perilaku peserta didik yang terlihat memperhatikan dan tertarik terhadap permasalahan yang diajukan oleh guru. Berdasarkan hal tersebut, maka pada tahap ini peserta didik dapat berpeluang untuk meningkatkan pemahaman konsep. Dengan demikian dapat disimpulkan bahwa secara simultan model project based learning memberikan kontribusi yang lebih baik terhadap peningkatan pemahaman konsep peserta didik dibandingkan dengan model guided inquiry.

Berdasarkan nilai rata-rata $\mathrm{N}$-gain pemahaman konsep biologi peserta didik yang diajar dengan model project based learning lebih baik dibandingkan dan model guided inquiry. Nilai rata-rata peningkatan ( $\mathrm{N}$-gain) kelas model project based learning dan di kelas model guided inquiry yaitu termasuk kategori tinggi pada indikator menafsirkan, mencontohkan, menyimpulkan dan membandingkan. Indikator menggelompokkan dan merangkum kelas model project based learning lebih tinggi dibandingkan nilai rata-rata peningkatan (N-gain) kelas model guided inquiry. Indikator menjelaskan kelas model projet based learning lebih rendah dibandingkan nilai rata-rata peningkatan ( $\mathrm{N}$-gain) model guided inquiry.

Perbedaan pemahaman konsep pada materi sistem ekskresi diperkuat dengan hasil analisis uji-t independent dengan nilai signifikansi ( $p$-value) yang diperoleh lebih kecil dari nilai alpha. Artinya, ada perbedaan yang signifikan pemahaman konsep sistem ekskresi menggunakan model project based learning dan model guided inquiry. Penerapan model project based learning lebih efektif dibandingkan dengan penerapan model guided inquiry dalam meningkatkan pemahaman konsep peserta didik. Hasil tersebut dapat ditunjukkan pada perbedaan rata-rata peserta didik yang diajar dengan model project based learning dan model guided inquiry yang bernilai positif mengindikasikan bahwa pemahaman konsep sistem ekskresi peserta didik yang diajar menggunakan model project based learning lebih tinggi dibandingkan dengan kelas yang diajar menggunakan model guided inquiry.

Hal ini ini sejalan dengan temuan Mulyani (2015) yang menunjukkan model project based learning lebih unggul daripada model guided inquiry. Peningkatan baik dari aspek 
peserta didik yang memiliki pemahaman konsep yang tinggi maupun peserta didik yang memiliki pemahaman konsep yang rendah. Peningkatan kemampuan pemahaman konsep peserta didik sangat penting di dalam pembelajaran biologi. Peningkatan pemahaman konsep memberikan arahan yang tepat dalam berpikir dan bekerja, dan membantu dalam menentukan keterkaitan sesuatu dengan yang lainnya dengan lebih akurat. Penugasanpenugasan pada project based learning akan merangsang seluruh indera peserta didik untuk mengerjakan tugas-tugas ataupun permasalahan-permasalahan yang diberikan oleh pengajar, sehingga peserta didik akan terbiasa aktif dalam menyelesaikan permasalahan yang ada.

\section{SIMPULAN}

Simpulan yang diperoleh yaitu: (1) Terdapat perbedaan yang signifikan pemahaman konsep pada materi sistem ekskresi antara peserta didik yang diajar dengan model pembelajaran project based learning dengan peserta didik yang diajar dengan model guided inquiry dibuktikan dengan adanya perbedaan nilai rata-rata posttest peserta didik dan nilai G-gain pada masing-masing indikator pemahaman konsep, (2) Peserta didik kelas model project based learning memperoleh peningkatan pemahaman konsep yang lebih tinggi secara signifikan dari kelompok peserta didik pada kelas model guided inquiry.

\section{SARAN}

Materi pembelajaran yang digunakan dalam penelitian ini terbatas pada pokok bahasan sistem ekskresi sehingga dapat dikatakan bahwa hasil penelitian terbatas hanya pada materi tersebut. Oleh karena itu, disarankan diadakan penelitian lebih lanjut terkait dengan perbandingan model pembelajaran project based learning dengan model pembelajaran dan materi biologi lainnya.

\section{DAFTAR PUSTAKA}

Bell, S. 2010. Project-Based Learning for the 21 st Century: Skills for the future. The Clearing House. Vol 83, 39-43. 
Cohen, L. Manion, L. Marrison, K. (2007). Research Methods in Education. London and New York: Routledge Falmer.

Diki, D. 2013. Creativity for Learning Biology in Higher Education. LUX: A Journal of Transdisciplinary Writing and Research from Claremont Graduate University: Vol. 3 Iss 1, 323-341.

Hakim, H. 2018. Pengaruh Model Pembelajaran Project Based learning (PjBL) terhadap Pemahaman Konsep Biologi, keterampilan Pemecahan Masalah, dan Pengetahuan Metakognitif Siswa Pada materi Sistem Pernapasan Manusia. Tesis, Kendari: Universitas Halu Oleo: tidak dipublikasikan.

Hasina, W. 2018. Perbandingan Efektivitas Model Pembelajaran Discovery Learning dan Problem Based Learning pada Pengembanbangan Kemampuan Berpikir Kritis dan Pemahaman Konsep SMA. Tesis, Kendari: Universitas Halu Oleo: tidak dipublikasikan.

Kementerian Pendidikan dan Kebudayaan. Laporan Hasil Ujian Nasional. Jakarta: Pusat Penilaian Pendidikan. https://puspendik.kemdikbud.go.id/hasil-un/diakses tanggal 18 Juni 2019.

Kunandar. 2007. Guru Profesional: Implementasi Kurikulum Tingkat Satuan Pendidikan (KTSP) dan Persiapan Mengahadapi Sertifikasi Guru. Jakarta: Rajagrafindo Persada.

Kurniawan, A. 2012. Implementasi Metode Pembelajaran Inquiry Terbimbing dan Inquiry bebas Termodifikasi terhadap Prestasi Belajar Biologi Ditinjau dari Kemampuan Awal dan Keingintahuan Peserta didik SMA. Tesis. Surakarta: Universitas Sebelas Maret. https://digilib.uns.ac.id/ di akses pada tanggal 10 Januari 2019.

Margono. 1995. Model Belajar Mengajar. Surakarta: Sebelas Maret University Press.

Mulyani, N. K. S. Karyasa, I. W. dan Suardana, I. N. 2015. Komparasi Peningkatan Keterampilan Berpikir Kritis dan Kinerja Ilmiah Peserta Didik yang Dibelajarkan dengan Model Project Based Learning dan Model Pembelajaran Guided Inquiry. E-Journal Program Pascasarjana Universitas Pendidikan Ganesha Program Studi Pendidikan IPA. Volume 5, 1-12.

Ong, A. C and Borich, G. D. 2006. Teaching Strategies that Promote Thingking "Models and Curriculum Approaches”. Singapore: McGraw-Hill Education (Asia).

Panasan and Nuangchalerm. 2010. Learning Outcomes of Project-Based and InquiryBased Learning Activities. Journal of Social Sciences. Vol. 6 No. 2, 252-255. 
Sanjaya, W. (2006). Strategi Pembelajaran Berorientasi Standar Proses Pendidikan. Jakarta: Kencana Prenada Media Group.

Thomas, J.W. 2000. A Review od Research on Project-Based Learning. California: The Autodesk Foundation.

http://www.bobpearlman.org/BestPractices/PBL_Research.pdf. Diakses pada tangal 18 Juni 2019. 